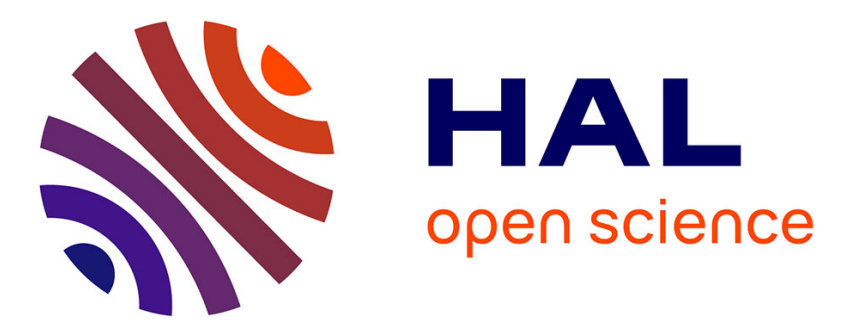

\title{
Miliacin in palaeosols from an Early Iron Age in Ukraine reveal in situ cultivation of broomcorn millet
}

Giedre Motuzaite-Matuzeviciute, Jérémy Jacob, Sergey Telizhenko, Martin K. Jones

\section{- To cite this version:}

Giedre Motuzaite-Matuzeviciute, Jérémy Jacob, Sergey Telizhenko, Martin K. Jones. Miliacin in palaeosols from an Early Iron Age in Ukraine reveal in situ cultivation of broomcorn millet. Archaeological and Anthropological Sciences, 2016, 8, pp.43-50. 10.1007/s12520-013-0142-7 . insu-00832347

\section{HAL Id: insu-00832347 \\ https://hal-insu.archives-ouvertes.fr/insu-00832347}

Submitted on 24 Sep 2013

HAL is a multi-disciplinary open access archive for the deposit and dissemination of scientific research documents, whether they are published or not. The documents may come from teaching and research institutions in France or abroad, or from public or private research centers.
L'archive ouverte pluridisciplinaire $\mathbf{H A L}$, est destinée au dépôt et à la diffusion de documents scientifiques de niveau recherche, publiés ou non, émanant des établissements d'enseignement et de recherche français ou étrangers, des laboratoires publics ou privés.

\section{(ㅇ)(1) $\$$}

Distributed under a Creative Commons Attribution - NonCommercial - NoDerivatives| 4.0 


\title{
Miliacin in palaeosols from an Early Iron Age in Ukraine reveal in situ cultivation of broomcorn millet
}

\author{
Giedre Motuzaite-Matuzeviciute ${ }^{1,2}$, Jérémy Jacob $^{3,4,5}$, Sergey Telizhenko ${ }^{6}$, Martin K. Jones ${ }^{7}$ \\ ${ }^{1}$ McDonald Institute for Archaeological Research, University of Cambridge, Downing Street, \\ Cambridge CB2 3ER Great Britain, UK \\ ${ }^{2}$ History Faculty/Department of Archaeology, Vilnius University, Universiteto 7, 01513 \\ Vilnius, Lithuania \\ ${ }^{3}$ Institut des Sciences de la Terre d'Orléans, Université d'Orléans, ISTO, UMR 7327, 45071 \\ Orléans, France \\ ${ }^{4}$ CNRS/INSU, ISTO, UMR 7327, 45071 Orléans, France \\ ${ }^{5}$ BRGM, ISTO, UMR 7327, BP 36009, 45060 Orléans, France \\ ${ }^{6}$ Institute of Archaeology in Crimea, National Academy of Science, of Ukraine, Yaltinskaya St. \\ 2, Simferopol 95007, Ukraine \\ ${ }^{7}$ Department of Archaeology, University of Cambridge, Downing Street, Cambridge CB2 3DZ \\ Great Britain, UK
}

\begin{abstract}
During the archaeobotanical investigation of Scythian-Sarmatian period (Early Iron Age), pits with crop processing waste, discovered in the floodplain of Donets River, eastern Ukraine, and charred remains of cereal grains, dominated by broomcorn millet, were recorded. The grains from the pits were radiocarbon dated to the fifth to first century BC. Those pits are distant from any known contemporaneous settlement. The apparent disconnection of these pits from any local settlement suggests that (1) millet was brought from other locations by mobile groups, or (2) millet was cultivated locally by populations whose settlements have left no discernible archaeological trace. The analysis of molecular biomarkers preserved in palaeosols that are stratigraphically connected to the pits revealed high levels of miliacin, a molecule that can be preserved in ancient soils and sediments, and that is consistent with broomcorn millet (Panicum miliaceum). High levels in miliacin in soils stratigraphically connected to the pits are interpreted as the result of a large biomass of P. miliaceum produced at time of soil formation. Our biogeochemical results applied to a palaeosol thus attest to the in situ cultivation of crops dominated by the broomcorn millet during the early Iron Age in the floodplain of Donets River. Biochemical examination of soils and palaeosols can thus provide useful information on past dynamics of land-use by ancient population, especially when settlements or macrobotanical remains are absent.
\end{abstract}

Keywords: Broomcorn millet cultivation, Scythian period, Sarmatian period, Ukraine, Miliacin. 


\section{Introduction}

Archaeological evidence for the trace amounts of agriculture in the Eurasian steppes is very sparse as a result of a low population density and a semi-nomadic way of life. Consequently, the occupation horizons in archaeological sites are rather thin and often unnoticed by archaeologists. Developing new approaches and methods would help in unravelling the subsistence and environmental adaptation strategies of populations that occupied the steppes. More generally, there is an emerging field of research aiming at deciphering past land-use strategies (Guilaine 1991). Currently, there are very few means for attesting the location of ancient crop fields (Boissinot 2000). Specific pedosignatures indicating cultivation such as ploughing features can, in favourable cases, be recognised from soil micromorphology (e.g. Macphail et al. 1990). The stratigraphy, sedimentology and pedology of fossil ditch fills, in association with the interpretation of aerial photographs and ground penetrating radar, can provide crucial information on the structure and geometry of ancient plots (i.e. Berger and Jung 1996; Berger 2000, 2005). The examination of intact phytoliths in conjunction with carbon isotopes analysis may allow the cultivation of specific crops to be attested at a given location (Harvey and Fuller 2005; Iriarte et al. 2010). In this paper, we demonstrate that the growth of millet can be identified from analysis of molecular biomarkers preserved in soils and sediments, thus attesting to the local cultivation of millet by people who otherwise leave little archaeological trace in that locale.

\section{Background}

On biomarker studies

In various archives such as soils, peats or sediments, fossil biogenic molecules, whose structure is sufficiently intact, can provide information on past vegetation, either natural or cultivated. The range of fossil molecules found in natural archives is constantly growing in the field of organic geochemistry, providing, for example, molecular biomarkers of Asteraceae (Lavrieux et al. 2011), Gramineae (Jacob et al. 2005), Pinaceae (Le Milbeau et al. 2013) and Lamiaceae (Huang et al. 2011). This range expands beyond the fossil molecules extracted from human artefacts within the frame of archaeological studies on settlements (i.e. Evershed 2008).

The biogeochemical analysis of Lake Le Bourget (French Alps) sediments revealed the presence of miliacin, a molecular biomarker that was characteristic of Panicum miliaceum (broomcorn millet), in the light of archaeobotanical, phytochemical and isotopic evidence (Jacob et al. 2008a, b, 2009). The presence of miliacin has been previously reported in millet crop processing pits in China detected together with broomcorn millet phytoliths (Lu et al. 2009). High levels in sediments dated back to the Bronze Age (1700-800 years cal BC) were interpreted as arising from intensive millet cultivation in the catchment area of the lake (Jacob et al. 2008a, b). When detected in the sediments of Lake Le Bourget, France (Jacob et al. 2008a, b, 2009), miliacin was the sole pentacyclic triterpene methyl ethers (PTME) identified. When detected in the sediments of a Brazilian lake, miliacin was accompanied by other PTMEs (Jacob et al. 2005). Its source was therefore only identified to the general taxonomic level of Poaceae. By comparing the list of miliacin-only PTMEs producers with a carpological inventory, Jacob et al. (2008) were able to constrain the source of miliacin to a smaller number of taxa, including P. miliaceum. Considering that miliacin, as other pentacyclic triterpenes, is rather resistant to diagenesis owing to the supposed antifungal/antibacterial role of pentacyclic triterpenes in plants, it is very likely that miliacin can survive in soils formerly used for millet cultivation. A recent study showed, for example, that soils developed in French Massif Central retain the chemical signature of a pasture more than 50 years after it was replaced by trees (Lavrieux et al. 2012). Such a discovery opens new perspectives for identifying soils that were used by past populations for crop cultivation. 
Miliacin as marker of broomcorn millet

Miliacin is a pentacyclic triterpene (a compound with 30 carbon atoms arranged into five rings) with an oleanane skeleton, a double bond between carbons 18 and 19 and a methoxy group

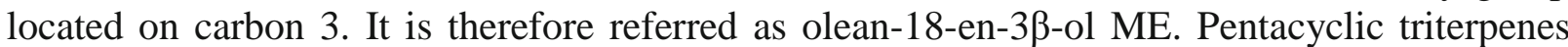
are widely distributed in the plant kingdom, but those bearing a methoxy group (pentacyclic triterpene methyl ethers, PTMEs) are rather rare, since they were only reported by phytochemists in a restricted number of plants (53 species), 45 of them being Poaceae (Ohmoto et al. 1970; Jacob et al. 2005). Ohmoto et al. (1970) concluded that miliacin is common throughout the Poaceae. In contrast, Jacob et al. (2005) argue that in combination with low quantities of other PTME (when miliacin is synthesized among PTMEs), it may be used as a biomarker for specific plants belonging to Panicum sp., Microstegium sp., Digitaria sp., Glyceria sp. and Pennisetum sp. It is important to note, however, that miliacin is especially concentrated in P. miliaceum in comparison with other species of plants bearing miliacin. When cultivated, this plant produces a large biomass that allows the use of sediments as a tracer for P. miliaceum production, as opposed to other plants growing as occasional weeds.

\section{Study site}

The Zanovskoe site is a seasonally-inundated alluvial plain of northern Donets River, situated in between two oxbow lakes: Matkino and Zanovskoe (Fig. 1). The floodplain contains the remains of man-made pits not visible from the surface. Charred macrofossils from flotation of those pits have indicated the presence of broomcorn millet P. miliaceum and barley (Hordeum vulgare) crops and their chaff, together with arable weeds and wetland plants (MotuzaiteMatuzeviciute et al. 2012). Broomcorn millet and barley grains in pits 14 and 18 have been directly AMS radiocarbon dated to 342-44 cal BC and 404-203 BC, thus implying that those pits were used during a period spanning the fifth to first centuries cal BC (MotuzaiteMatuzeviciute et al. 2012), with pit 14 being slightly younger that pit 18 (see below for information on pits 14 and 18).

\section{Material and methods}

Sampling

The samples for miliacin were taken from a stratigraphic section within a $10 \times 5 \mathrm{~m}$ excavation area, located 4 to $5 \mathrm{~m}$ south of the excavated pits that had yielded broomcorn millet macrofossils, i.e. closer to Donets River. From the stratigraphic sections, revealed during the excavation, it was observed that the upper boundary of the A-horizon of palaeosol varies in depth and deepens in the direction of the river bed. Taking this slight slope of the A-horizon into account, samples were collected from depths estimated to lie at the tops of both pits, thus potentially integrating the palaeosurface corresponding to the age of the pits. Kubiena tins for intact micromorphology sampling were used to take sediment blocks from section. Four blocks in total, each $7.5 \mathrm{~cm}$ length, $5.5 \mathrm{~cm}$ breadth and $4 \mathrm{~cm}$ depth, were taken from $74 \mathrm{~cm}$ to $114 \mathrm{~cm}$ depths. Initially, those samples were intended to be used for micromorphological analysis for clarification of the stratigraphic sequence of the site. However, the recovery of charred millet grains through flotation presented an opportunity to conduct a small pilot study exploring the presence of miliacin in the sediments. The stratigraphy of the Zanovskoe site comprises a palaeosol formed within loess, overlain by well-sorted alluvial sediments, in which the current soil is formed. The sedimentary layers and palaeosol slope gently towards the river (Fig. 2a). The excavated pits are discernible within the palaeosol A-horizon and presumed to have been cut through that soil and infilled prior to alluvial inundation. The Kubiena tins samples we took from the same A-horizon, through which it is inferred, these pits were cut. Thus, in stratigraphic terms, the charred millet remains, and the Kubiena tins are coeval, though we are not at present 
able to infer the precision of that contemporaneity. The samples for miliacin analysis were brought to the soil laboratory at the Department of Geography, University of Cambridge. One cubic centimetre sediment sample was taken from each block, every centimetre using pollen sampling tools. The samples were sent for miliacin analysis to the Institut des Sciences de la Terre d'Orléans, France.

The detection and quantification of miliacin and other biomarkers

An aliquot (ca. $2 \mathrm{~g}$ ) of each sample was extracted by automatic solvent extraction with a Dionex® ASE 200, using a mixture of $\mathrm{CH} 2 \mathrm{Cl} 2: \mathrm{MeOH}(9: 1 \mathrm{v} / \mathrm{v})$. The total lipid extract was separated into neutral, acidic and polar fractions by solid phase extraction realised on aminopropyl-bonded silica, as described by Jacob et al. (2005). The neutral lipid fraction was further separated into aliphatics, aromatics, ethers and esters, acetates and ketones and alcohols by flash chromatography on a Pasteur pipette filled with activated silica $\left(24 \mathrm{~h}\right.$ at $120{ }^{\circ} \mathrm{C}$, then deactivated with $5 \% \mathrm{H} 2 \mathrm{O}$ ), using a sequence of solvents of increasing polarity. After addition of $5 \alpha$-cholestane as a quantitation standard, the ethers-esters (that contain miliacin) and acetate-ketones (that contain taraxeryl and bauerenyl acetates, taraxerone and friedelin) fractions were analyzed by GC/MS on a Trace GC Ultra gas chromatograph coupled to a TSQ Quantum XLS mass spectrometer equipped with an AS 3000 autosampler (both from ThermoScientific, Bremen, Germany). The GC was fitted with a TG-5 MS capillary column (60 m, $0.25 \mathrm{~mm}$, i.e. $0.25 \mu \mathrm{m}$ film thickness; Thermo, Bellefonte, PA, USA). The temperature of the column was held at $40{ }^{\circ} \mathrm{C}$ for $1 \mathrm{~min}$ and then increased from 40 to $120^{\circ} \mathrm{C}$ at $30{ }^{\circ} \mathrm{C} \mathrm{min}-1$ and then from 120 to $300{ }^{\circ} \mathrm{C}$ at $3{ }^{\circ} \mathrm{C} \mathrm{min}-1$, with a final isothermal hold at $300{ }^{\circ} \mathrm{C}$ for $70 \mathrm{~min}$. The sample was dissolved in toluene, and $2 \mu \mathrm{L}$ was injected in splitless mode at $280{ }^{\circ} \mathrm{C}$. The carrier gas was helium at a flow rate of $1.0 \mathrm{~mL}$ min-1. The mass spectrometer was operated in the electron ionisation mode at $70 \mathrm{eV}$ and scanned from m/z 50 to 600. Miliacin, taraxeryl and bauerenyl acetates were identified by using an authentic standard. Friedelin and taraxerone were identified by comparing their mass spectra with literature data. Due to low levels, miliacin was quantified by comparing the area of its peak on the $\mathrm{m} / \mathrm{z} 189+204+218$ ion specific (Fig. 3) chromatogram with that of $5 \alpha$-cholestane on the total ion current (TIC) after applying a correction factor for the contribution of fragments $\mathrm{m} / \mathrm{z} 189+204+218$ to the entire mass spectrum of miliacin. For other compounds detected (taraxeryl and bauerenyl acetates, taraxerone and friedelin), the area was directly measured on the TIC. Concentrations in miliacin and other compounds are expressed as nanogramme per gramme sediment.

Results and discussion

Vertical distribution of molecular biomarkers Miliacin as the sole PTME was detected in 14 of the 22 sediment samples collected at 74-114 cm depth at the Zanovskoe site (Fig. 3). Samples below $100 \mathrm{~cm}$ depth did not show any miliacin, whereas they afforded measurable amounts of all other higher plant pentacyclic triterpenes identified and quantified (taraxeryl acetate, bauerenyl acetate, taraxerone and friedelin; Fig. 3). The presence of pits nearby, in which charred P. miliaceum was the principal taxon, supports an inference of broomcorn millet being a sole PTME plant source.

We also compared distinct dynamics of miliacin in the Zanovskoe section to other pentacyclic triterpenes that do not have the methoxy function and therefore are not suggestive of $P$. miliaceum. The vertical distribution of these triterpenes contrasts with miliacin, which is only attested by significant amounts (i.e. concentrations ranging from 3 to $15 \mathrm{ng} \mathrm{g}-1$ soil) at sampling depths between 70 and $100 \mathrm{~cm}$, corresponding to the A-horizon of the palaeosol. We do not have data from $70 \mathrm{~cm}$ with which to compare these; the data we have, however, indicate an association between the higher miliacin levels and the horizon through which the milletbearing pits were cut. 
Taraxerone and friedelin are commonly found in many angiosperms and are therefore reputed molecular tracers of these plants when found in sediments (i.e. Cranwell 1984). Although they might occur in other plants, taraxeryl and bauerenyl acetates frequently found in Asteraceae, and therefore, proposed as diagnostic biomarkers for these plants (Lavrieux et al. 2011). The singular behaviour of miliacin in the palaeosols compared to other pentacyclic triterpenes rules out any diagenetic or transportation process explaining the distribution of miliacin because all these pentacyclic triterpenes should be similarly affected by these processes. Conversely, the comparison of miliacin with other pentacyclic triterpenes can only be explained by the presence/absence of the source organisms at time soils formed. Discussing the evolution of concentrations in taraxeryl and bauerenyl acetates, taraxerone and friedelin is out the scope of this paper but would certainly relate to the presence of weeds and other associated species.

\section{Soil molecular imprints of former cropping}

The detection of miliacin in the palaeosol into which the pits were cut implies that the presence of sufficient biomass of its plant source (P. miliaceum) broadly around the time the pits were in use to yield measurable amounts of miliacin. This can only occur if P. miliaceum plant was directly growing in the soils sampled, if the surfaces of these soils were used to process $\mathrm{P}$. miliaceum after harvesting or manure with broomcorn millet remains was used to fertilise the fields. It also should be mentioned that in the pits together with broomcorn millet charred macrofossils (four in total), caryopses of Digitaria sanguinalis were identified, which potentially contributed to miliacin levels in the sediments, as it is one of the plant species known to produce sole PTME.

However, it would need to be a dominant plant to produce quantities such as recovered in the Zanovskoe section. On the basis of the macrobotanical data from the pits 14 and 18 that seems unlikely (Motuzaite-Matuzeviciute et al. 2012). The preservation of miliacin in palaeosols is unsurprising, as this molecule has been found in the sediments of a Brazilian lake dating back to several thousand years without suffering an intensive degradation (Jacob et al. 2005). This high preservation potential of miliacin is undoubtedly related to the supposed antifungal/antibacterial role of miliacin and other pentacyclic triterpenes in plants. The detection of miliacin in the Zanovskoe palaeosol concurs with recent results showing that the chemical imprint of soils can attest to their former usage. When these soils and sediments are anthropogenic in origin and found in association with archaeological sites, the spatial distribution of organic chemicals can be used to identify areas used in specific tasks. For example, this approach has been successfully applied to unravel funerary practices in the Qatna tomb (Syria), through the mapping of Royal Purple (James et al. 2009), to decipher zones of activities in an Iron Age house through the analysis of lipids (Hjulström and Isaksson 2009).

Beyond the settlement nucleus, organic geochemistry applied to soils allowed identifying areas of manuring through the quantitation of faecal sterols (Evershed et al. 1997; Bull et al. 1998). Lavrieux et al. (2011) showed that the recent (<60 years) transition from a pasture to a conifer forest in the French Massif Central is recorded in the chemical imprint of soils. Although soils presently exhibit a clear molecular signature of the surrounding conifer vegetation, molecular biomarkers specific to pastures (pentacyclic triterpenyl acetates, for example) are still preserved in the soil profile. Here, by using a molecular biomarker that is characteristic of a cultivated plant, we are able to attest to the former utilization of a soil for the cultivation of one particular crop-broomcorn millet. These results should be spatially extended through biogeochemical mapping of soils and palaeosols in order to unravel past strategies in land-use.

Millet cultivation at Zanovskoe during the Iron Age

The eastern territory of Ukraine has long been considered terra incognita for the Early Iron Age period (Grechko 2010). Only a few settlement sites from the late Scythian- Early Sarmatian 
period have been found in this vast territory, and these are located northwest or southeast from the Zanovskoe site, at the tributaries of Donets River or at the Don River (MotuzaiteMatuzeviciute et al. 2012). The nearest sites contemporary to Zanovskoe Scythian-Sarmatian period settlements-Velyka Gomolsha, Rusky Bishkin, Cherkasky Bishkin and Komsomolskoe - are around 170-200 km away from Zanovskoe (Radzievskaya and Shramko 1990; Grechko 2010). The steppe zone of Ukraine during the Early Iron Age period was thought to be controlled by warlike nomadic groups, which were not involved in agriculture themselves and whose subsistence were mainly based on pastoralism and meat/milk-based diet (e.g. Grechko 2010; Radzievskaya and Shramko 1990). Evidence of in situ broomcorn millet cultivation in the steppe zone of Ukraine challenges that notion.

The fluctuating miliacin quantities across the stratigraphy could be an indication that Donets river flood-pain was repeatedly used for growing millet. Such a multiple period use of the site for crop cultivation might also be inferred from the AMS radiocarbon dates of the charred cereal grains from two pits published in Motuzaite Matuzeviciute et al. (2012). As mentioned earlier in the text, no sites contemporaneous to those agricultural fields have yet been found in the region, and the yearly inundation of the Donets floodplain suggest that people seasonally came to use those fields from somewhere else. The discovery of in situ crop cultivation sheds some light on cropping strategies of the local populations and their social organisation during the Early Iron Age period in Ukraine. We may note interesting parallels among nineteenth century records of central Asian societies. Tuvan and Mongolian nomads sowed their crops in spring fields at some distance from the camp and then moved to summer pastures. The spring, summer and autumn camps were located in river valleys along the foothills or larger river. After a couple of months, they returned to their spring camps to collect grain. Part of the crops were taken to winter camps, while enough grain for spring sowing were left in a pits in the spring fields (Rona-Tas 1959; Vainshtein 1980).

\section{Conclusion}

Our research has showed that miliacin biomarker preserved in palaeosols for thousands of years may relate to ancient millet cultivation in the ancient landscape. Miliacin biomarker analysis may contribute to our understanding of the cropping strategies of early mobile communities, especially in areas which lack discernible archaeological sites.

\section{Acknowledgments}

Leverhulme Trust, European Research Council, Research Council of Lithuania (project no. VP1-3.1-ŠMM-01-V-02- 004), Gates Trust and Arts and Humanities Research Council, the PaléoChamps project (AIR Archéométrie, CNRS) to J.J.

\section{References}

Berger JF (2000) Les fossés bordiers historiques et l'histoire agraire rhodanienne. Études rurales, La très longue durée. http://etudesrurales.revues.org/document1.html. Accessed 24 September 2012

Berger JF (2005) Sédiments, dynamique du peuplement et climat au Néolithique ancien. In: Guilaine J (ed) Populations néolithiques et environnements. Séminaire du Collège de France. Errance, Paris, pp 155-212

Berger JF, Jung C (1996) Fonction, évolution et «taphonomie » des parcellaires en moyenne vallée du Rhône. Un exemple d'approche intégrée en archéomorphologie et en géoarchéologie. In: Chouquer G (ed) Les formes du paysage. Tome 2: Archéologie des parcellaires. Errance, Paris, pp 95-112

Boissinot P (2000) A la trace des paysages agraires. Études rurales, La très longue durée. http://etudesrurales.revues.org/document1.html.Accessed 24 September 2012 
Bull ID, van Bergen PF, Poulton PR, Evershed RP (1998) Organic geochemical studies of soils from the Rothamsted classical experiments-II: soils from the Hoosfield Spring Barley Experiment treated with different quantities of manure. Org Geochem 28:11-26

Cranwell PA (1984) Organic geochemistry of lacustrine sediments: triterpenoids of higher plant origin reflecting postglacial vegetational succession. In: Haworth EY, Lund JWG (eds) Lake Sediments and Environmental History. University Press, Leicester, pp 69-92

Evershed RP (2008) Organic residue analysis in archaeology: the archaeological biomarker revolution. Archaeometry 50(6):895-924

Evershed RP, Bethell PH, Reynolds PJ, Walsh NJ (1997) 5betastigmastanol and related 5betastanols as biomarkers of manuring: analyses of modern experimental material and assessment of archaeological potential. J Arch Sci 24:485-495

Grechko DS (2010) Naselennya skifskogo chasu na Siverskomu Dintsi. Kiiv, Institut arkheologii NAD Ukraini Guilaine J (1991) Pour une archéologie agraire. Armand Colin, Paris

Harvey EL, Fuller DQ (2005) Investigating crop processing using phytolith analysis: the example of rice and millets. J Arch Sci 32:739-752

Hjulström B, Isaksson S (2009) Identification of activity area signatures in a reconstructed Iron Age house by combining element and lipid analyses of sediments. J Arch Sci 36:174183

Huang X, Meyers PA, Wu W, Jia C, Xie S (2011) Significance of long chain iso and anteiso monomethyl alkanes in the Lamiaceae (mint family). Org Geochem 42:156-165

Iriarte J, Glaser B, Watling J, Wainwright A, Birk JJ, Renard D, Rostain S, McKey D (2010) Late Holocene Neotropical agricultural landscapes: Phytolith and stable carbon isotope analysis of raised fields from French Guianan coastal savannahs. J Arch Sci 37:29842994

Jacob J, Disnar JR, Boussafir M, Sifeddine A, Albuquerque ALS, Turcq B (2005) Pentacyclic triterpene methyl ethers in recent lacustrine sediments (Lagoa do Caçó, Brazil). Org Geochem 36:449-461

Jacob J, Disnar JR, Arnaud F, Chapron E, Debret M, Lallier-Vergès E, Desmet M, RevelRolland M (2008a) Millet cultivation history in the French Alps as evidenced by a sedimentary molecule. J Arch Sci 35:814-820

Jacob J, Disnar JR, Bardoux G (2008b) Carbon isotope evidence for sedimentary miliacin as a tracer of Panicum miliaceum (broomcorn millet) in the sediments of Lake Le Bourget (French Alps). Org Geochem 39:1077-1080

Jacob J, Disnar JR, Arnaud F, Gauthier E, Billaud Y, Chapron E, Bardoux G(2009) Impacts of newagricultural practises on soil erosion during the Bronze Age in French Prealps. Holocene 19:241-249

James MA, Reifarth N, Mukherjee AJ, Crump MP, Gates PJ, Sandor P, Robertson F, Pfälzner P, Evershed RP (2009) High prestige Royal Purple dyed textiles from the Bronze Age royal tomb at Qatna, Syria. Antiquity 83:1109-1118

Lavrieux M, Jacob J, LeMilbeau C, Zocatelli R, Masuda K, Bréheret JG, Disnar JR (2011) Occurrence of triterpenyl acetates in soil and their potential as chemotaxonomical markers of Asteraceae. Org Geochem 42:1315-1323

Lavrieux M, Bréheret JG, Disnar JR, Jacob J, LeMilbeau C, Zocatelli R (2012) Preservation of an ancient grassland biomarker signature in a forest soil from the French Massif Central. Org Geochem 51:1-10

Le Milbeau C, Lavrieux M, Jacob J, Zocatelli R, Disnar JR (2013) Diversity of methoxyserratenes in a soil under a conifer forest evidences their potential as biomarkers of Pinaceae. Org Geochem 55:45-54 
Lu H, Zhang J et al (2009) Earliest domestication of common millet (Panicum miliaceum) in East Asia extended to 10,000 years ago. Proc Natl Acad Sci 106:1-6

Macphail RI, Courty MA, Gebhardt A (1990) Soil micromorphological evidence of early agriculture in northwest Europe. World Arch 22:53-69

Motuzaite-Matuzeviciute G, Telizhenko S, Jones MK (2012) Archaeobotanical investigation of two Scythian-Sarmatian period pits in eastern Ukraine: implications for floodplain cereal cultivation. J Field Arch 37:51-60

Ohmoto T, Ikuse M, Natori S (1970) Triterpenoids of the Gramineae. Phytochemistry 9:21372148

Radzievskaya V E and Shramko IB (1990) Goncharnye pechi skifskoi epokhi v basseine Severskogo Dontsa. In: Brovender YM (ed)

Problemy issledovaniya pamyatnikov arkheologii Severskogo Dontsa. Tezisy dokladov oblastnoi nauchnoi-prakticheskoi konferentsii. Lugansk, Oblastnoi kraevedecheskiimuzei, pp 165-167

Rona-Tas A (1959) Some data on the agriculture of the Mongolia. In: Bodrogi T, Boglar L (eds) Opuscula ethnologica memoriae ludovici biro sacra. Akademiai Kiado, Budapest, pp 443-467

Vainshtein SI (1980) Nomads of South Siberia. Cambridge University Press, Cambridge

\section{Figure captions}

Fig. 1 Location of Zanovskoe site (shown in black square) (a) and the floodplain areawhere the site is situated (b) after (Motuzaite-Matuzeviciute et al. 2012)

Fig. 2 The stratigraphy of Zanovskoe site. The pits 14 and 18 in which charred millet seeds were found are shown on the left side of the section. On the right side of the section the position of the Kubiena boxes taken for miliacin quantitation are indicated (a). Note that the position of the pits is not in straight north-south line with the position of sediment sample. Evolution of miliacin, taraxeryl acetate, bauerenyl acetate, taraxerone and friedelin concentrations in the sediments of Zanovskoe (b). The section in which the Kubiena boxes were retrieved corresponds to that of the figure (Fig. 2a)

Fig. 3 Partial chromatograms (35-44 min) of the ethers-esters fraction of sample collected at 74 $\mathrm{cm}$ depth, illustrating the peaks of $5 \alpha$-cholestane and of miliacin (with structure) on the $\mathrm{m} / \mathrm{z}$ $189+204+218$ ion specific chromatogram. 


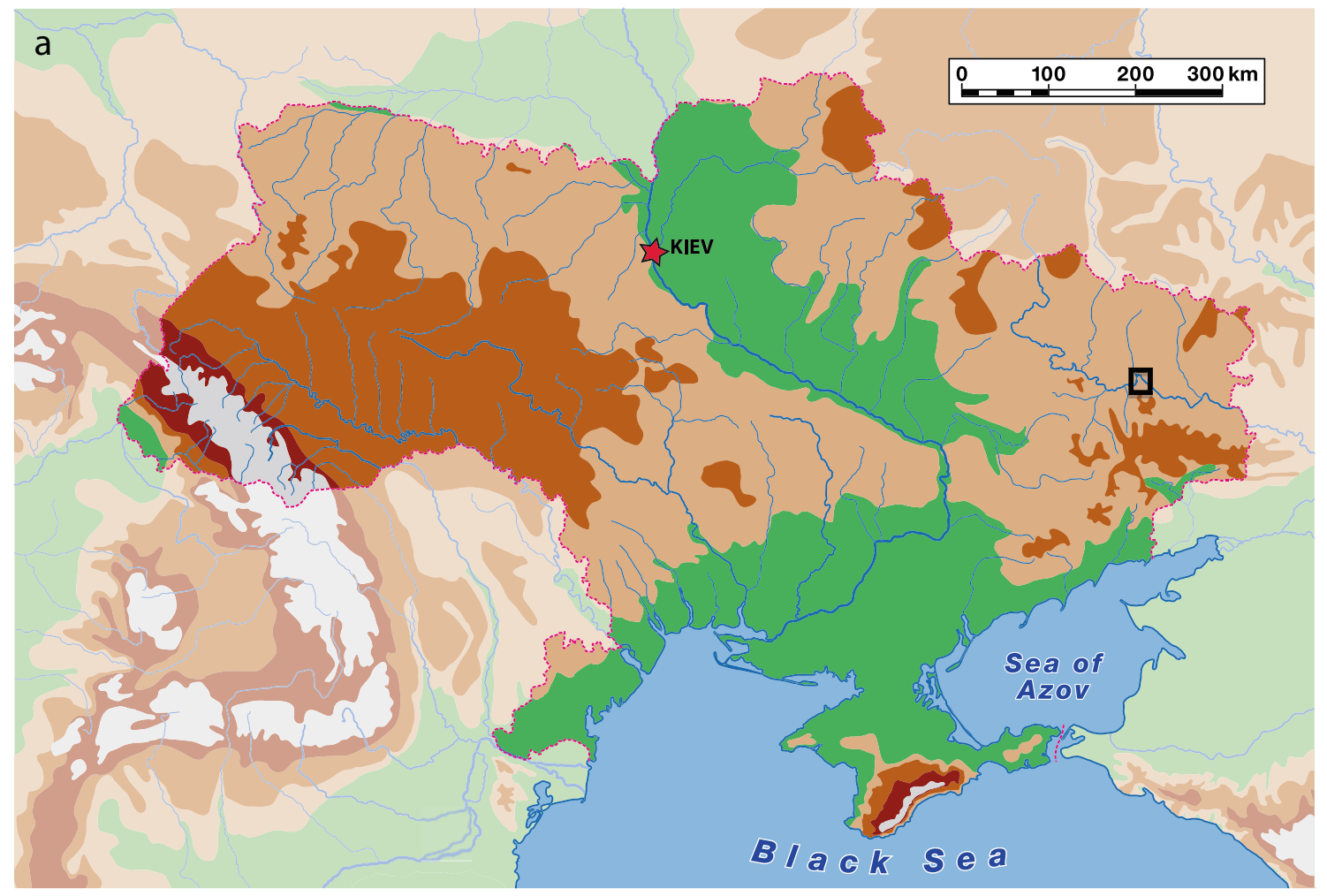

b

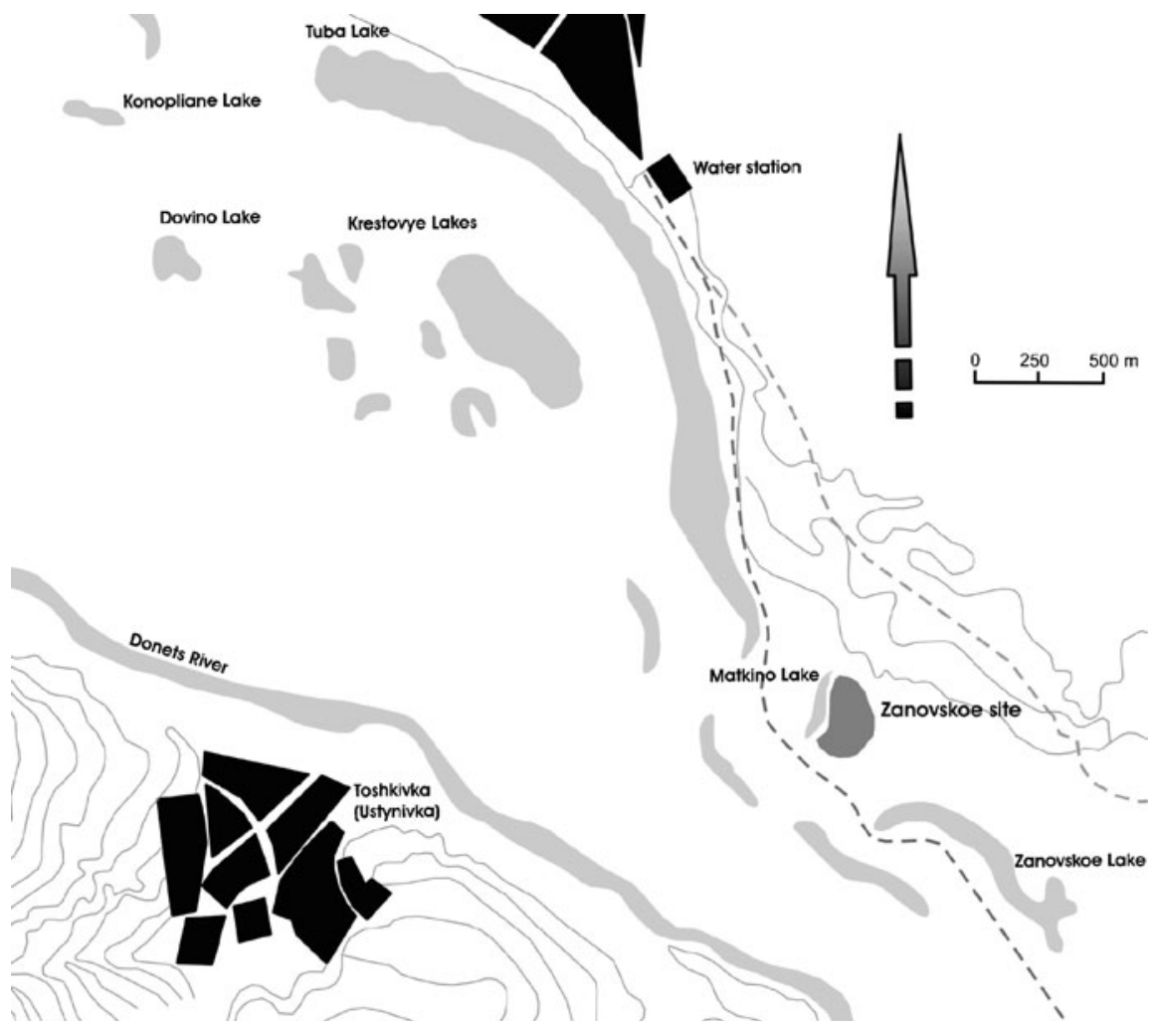


a

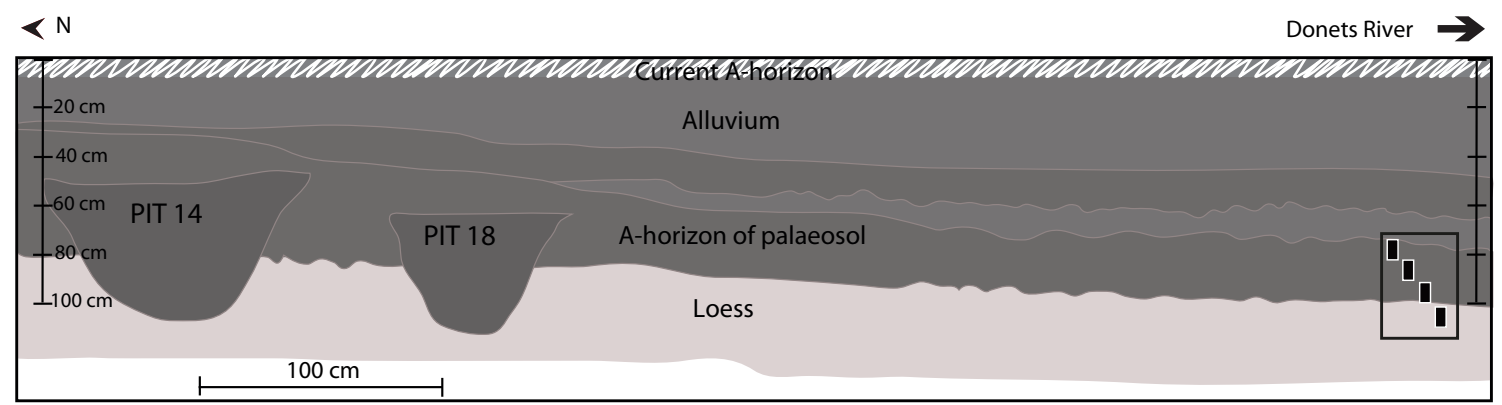

b

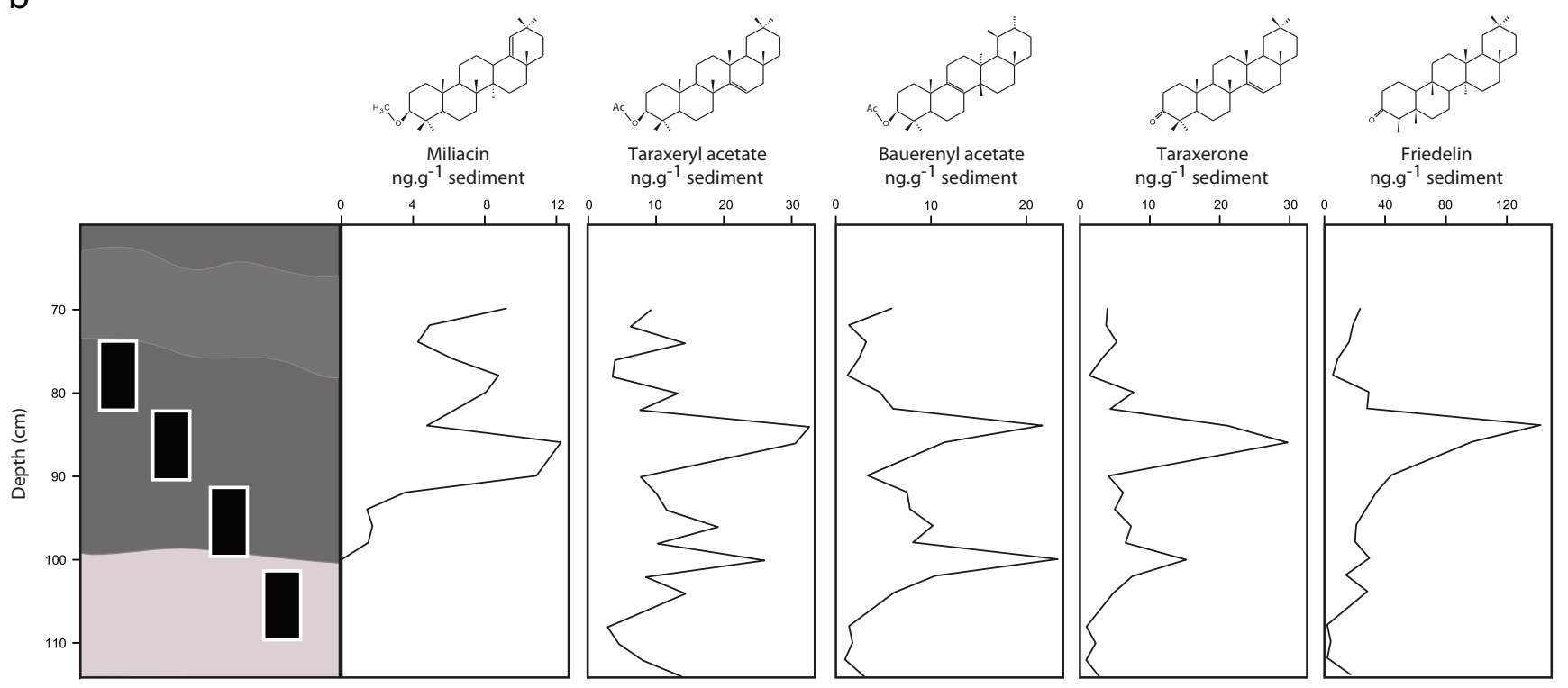




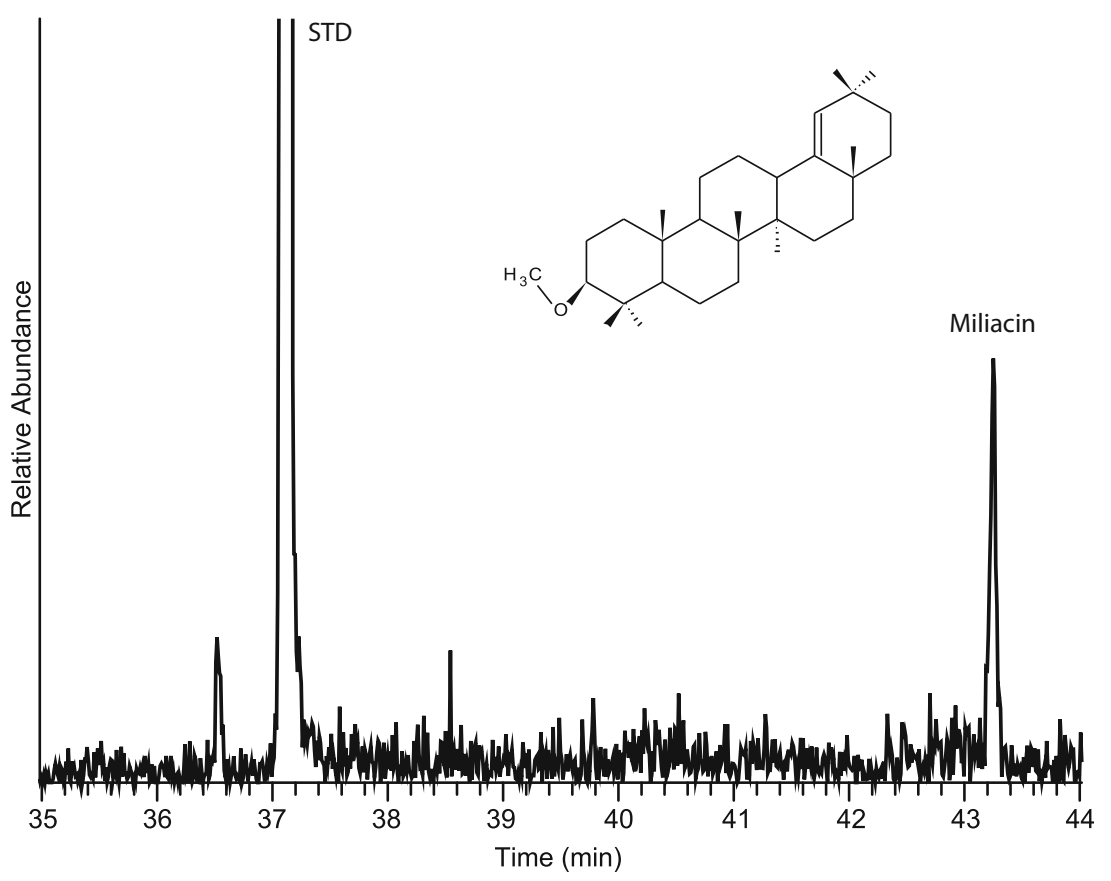

